\title{
Henri Lauzière
}

\section{THE CONSTRUCTION OF SALAFIYYA: RECONSIDERING SALAFISM FROM THE PERSPEGTIVE OF CONGEPTUAL HISTORY}

For nearly a century of scholarship, uncertainties and paradoxes have beleaguered interpretations of the origins and meaning of Salafism (al-salafiyya). Although academics and journalists alike are well aware of the various definitions and conflicting narratives of Salafism, relieving some of the confusion that beclouds the term continues to prove difficult. Given that concepts are fluid and relational, this state of affairs may seem inevitable. Yet there are reasons to believe that the current confusion surrounding Salafism is in part attributable to faulty scholarship and that consequently the substance and history of this religious orientation will remain unnecessarily puzzling so long as the production of knowledge about Salafism goes unexamined. In that sense, recent scholarly efforts to remedy the situation by providing deeper insights into the intellectual, geographical, and political diversity of Salafism have produced mixed results, for they have largely overlooked two of the most persistent epistemological problems that are at the root of much of the present-day ambiguity. ${ }^{1}$

First, the notion of Salafism has become a victim of its own success and, as a result, has often been used loosely and without due regard to its historicity. Indeed, many studies have affirmed the existence of Salafism at various points in history from the 9th to the 21 st centuries even when evidence for such claims has been tenuous, undisclosed, or even nonexistent. ${ }^{2}$ Over time, this relative lack of rigor in the secondary literature has perpetuated and validated the otherwise arguable idea that each era has had its own version of salafiyya. The insidious consequences of this counter-historical slip, which neglects the process by which the conceptualization of Salafism developed, should not be ignored. A parallel example is the confusion that can arise between the concept of "Enlightenment," which emerged at a specific time in 18th-century France and Germany, and the intellectual features that this label came to represent, such as rationality, which has no chronological or geographical limits per se. Hence, speaking about medieval "classic salafiyya," however useful, might prove as questionable as referring to "the Renaissance Enlightenment" of the 14 th century. ${ }^{3}$ How and why scholars use the concepts salafiyya and "Salafism" to make sense of Islamic intellectual history are thus questions that need to be addressed.

Henri Lauzière is an Assistant Professor in the Department of History, Northwestern University, Evanston, Ill.; e-mail: h-lauziere@northwestern.edu

(C) Cambridge University Press 2010 0020-7438/10 \$15.00 
Second, one subnarrative of Salafism has become something of an anomaly in recent years, for it seems largely incongruent with the now prevailing conception of Salafi Islam. For decades, a majority of scholars in the West, together with a few scholars and self-proclaimed Salafi activists in the Muslim world, conceived of salafiyya as an enlightened reform movement aimed at the revival and progress of Islam and Muslim societies in the modern era. Accordingly, the term conveyed an open and flexible religious approach that was associated with Islamic modernism and the work of major reformist figures such as Jamal al-Din al-Afghani (d. 1897), Muhammad 'Abduh (d. 1905), and Rashid Rida (d. 1935). ${ }^{4}$ This modernist understanding of Salafism differs markedly from the standard definitions of contemporary Salafism. Today, salafiyya is first and foremost a label that Sunni purists use to designate their approach to Islam. The term is usually understood to refer to a rigorist creed and religious methodology that share a "family resemblance" (to use Wittgenstein's expression) to Wahhabism or are intimately linked to the religious establishment of Saudi Arabia. To ensure the purity of Islam as they define it, contemporary Salafis articulate a very demanding interpretation of monotheism, which has the consequence of making unbelief more likely. They also advocate an expansive definition of innovation ( bid $^{\prime} a$ ), which narrows the scope of acceptable Islamic practice, and they remain wary of extrascriptural influences and sources of knowledge in religious matters. The extent of the gap between modernist and purist Salafism is an issue that specialists now acknowledge. It has caused enough uncertainty in the scholarship to warrant further investigation. ${ }^{5}$ Fitting the modernist anomaly into the prevailing paradigm of salafiyya still poses difficulties that are easier to sidestep than to overcome.

These intertwined problems call for a reconsideration of the assumptions underpinning the production of Islamic intellectual history. Hence, this article aims to disentangle and reevaluate some of the multiple layers of meaning that have been attached to the word salafiyya. More specifically, it identifies key historical circumstances and steps through which the notion of Salafism took shape and expanded in meaning. My point of departure is an observation made in 1988 by the Syrian mufti Muhammad Sa id Ramadan al-Buti. In his seminal critique of the contemporary Salafi methodology, al-Buti blamed the Islamic modernists of the late 19th century for creating the label salafiyya and turning it into a slogan to mobilize popular support. Although his analysis suffers from empirical and chronological defects, al-Buti aptly remarked that Islamic modernists eventually used the term salafiyya to name, among other things, their publishing houses. ${ }^{6}$ Without a doubt, the most famous of these establishments was the Salafiyya Press and Bookstore of Cairo, whose founders and managers were Muhibb al-Din al-Khatib (d. 1969) and 'Abd al-Fattah Qatlan (d. 1931), two Syrian émigrés connected with modernist Salafi networks. As a unit of analysis, the Salafiyya Press and Bookstore offers a privileged vantage point from which to examine the conceptual history of Salafism.

This article presents a threefold argument. First, the Salafiyya Press and Bookstore played a key role in the advent of the notion of "Salafism" by giving the term salafiyya unprecedented visibility. Implicit in this statement is the contention that salafiyya did not blossom as a slogan or as a conceptual construct until the early 20th century. Second, the Salafiyya Press and Bookstore, through its publications and editing choices, involuntarily contributed to shaping the contours of what constituted Salafism. In other words, it influenced the perceived meaning of salafiyya and led some observers to 
believe that the term stood for a broad movement of Islamic modernism, even though this assumption was-and remains-insufficiently documented. Third, the evolution of the Salafiyya Press and Bookstore shows that the commodification of Salafi epithets fueled a degree of ambiguity sufficient to facilitate the conceptual convergence of Salafism and Wahhabism as early as the 1920 s.

WHY CONCEPTUAL HISTORY?

A careful discussion of Salafism's history should begin by distinguishing two levels of analysis that are often blurred. The first pertains to the history of ideas and consists of tracing the origins of the methodology, beliefs, and practices that characterize Salafism today, including, for example, its antirationalist theology and heavy reliance on hadith literature. From such a perspective, Salafism may be said to go back, at least in part, to the time of Ahmad ibn Hanbal (d. 855). ${ }^{7}$ However, this approach can generate considerable confusion unless it is understood that the history of ideas differs from the history of the label under which these ideas were subsumed at a particular time. The second level of analysis is therefore conceptual: it redirects the focus of historical investigation toward the emergence, construction, and evolution of the notion of salafiyya (Salafism) as a typological category. When and where did this concept appear? Who developed it and truly popularized it? How and when did various methodologies, beliefs, and ideas become associated with it? Although this line of inquiry is not sufficient in itself to explain the ideational content of what is now known as Salafism, it has the capacity to disclose significant problems in the scholarship and to refine narratives that proceed from intellectual genealogy.

The idea that salafiyya is a religious orientation dating from the medieval period, although conceivable from the perspective of the history of ideas, is problematic at the conceptual level. Despite some suggestions to the contrary, there remains no conclusive evidence that medieval Muslim scholars used the word salafiyya as a substantive meaning Salafism. In a recent study, historian Bernard Haykel quotes a fatwa in which Ibn Taymiyya (d. 1328) uses the Arabic noun al-salafiyya, thus showing that Salafi epithets existed well before the modern era. ${ }^{8}$ Although Haykel left salafiyya untranslated, his contribution has quickly been taken to mean that a single noun translatable as "Salafism" goes back to the medieval period. ${ }^{9}$ Primary sources, however, do not explicitly corroborate this claim. Judging from context, and given the way in which Ibn Taymiyya handles the term in his corpus, it appears that al-salafiyya as mentioned in the said fatwa is a collective noun rather than a substantive. In other words, it is more likely to mean "the Salafis" than "Salafism" (just as al-sūfiyya means "the Sufis," not "Sufism"). ${ }^{10}$ In 2000 , a Saudi-based scholar reached the same conclusion while translating the passage into English on behalf of the Al-Imam Muhammad ibn Sa 'ud Islamic University in Riyadh. ${ }^{11}$

It would, of course, be shortsighted to overemphasize words at the expense of ideas. (The history of nationalist movements, for instance, could not be reduced to the presence of the word "nationalism" in the sources.) Yet dismissing the question of terminology would also strip Salafism of a certain historical dimension from which valuable insights can emerge. Moreover, it is a dimension that contemporary Salafis consider important. Unlike Sufis, who readily acknowledge that the word "Sufism" (tasawwuf) was unknown to the first Muslims and only later came to designate an older type of Islamic piety, Salafis 


\section{Henri Lauzière}

are often eager to prove that the terms they use are as old and legitimate as the pristine Islam to which they refer. ${ }^{12}$ Over time, they have therefore assembled several passages from medieval texts-reproduced in numerous books, pamphlets, and websites - that mention the word salafi $\bar{l}$, as either an adjective or a noun. ${ }^{13}$ Although absence of proof is not proof of absence, the fact that none of these quotations mentions salafiyya as a substantive (Salafism) is interesting, not because it solves a historical question but because it raises one. Why is today's omnipresent concept of salafiyya so difficult to find in premodern sources that even contemporary Salafis seem unable to locate it?

To argue that the concept could not have existed before the age of modern ideologies (or "isms") is not an entirely satisfactory way of settling the issue. After all, the presence of Salafi epithets (adjectives, nouns, and collective nouns) in Islamic texts since at least the 12th century suggests the existence of a corresponding concept. However, that concept does not seem to have been known as al-salafiyya. Rather, there is evidence that being a "Salafi" in the medieval period meant abiding by the doctrine of the forefathers (madhhab al-salaf) in matters of dogma and theology (ușül al-dīn). ${ }^{14}$ Written sources make it clear that medieval scholars used the notion of madhhab al-salaf primarily in theological contexts, where it served as an authoritative and prestigious synonym for the Hanbali creed ('aqī $d a$ ). ${ }^{15}$ In essence, it harked back to the idealized state of theological purity that existed in early Islamic history, when Muslims had not yet faced the challenge of speculative theology ( $k a l a \bar{m})$ and had not yet embarked on a systematic search for answers regarding the nature of God and the Qur'an. Therefore, the proponents of the madhhab al-salaf distanced themselves from those theologians-mainly, Jahmis, $\mathrm{Mu}$ 'tazilis, and Ash'aris—who first intellectualized the divine attributes (al-sifät) and, consequently, generated or encouraged debates within the community. By the same token, medieval Salafis usually distrusted the epistemological tools and traditions of Greek inspiration that underpinned such intellectual endeavors, including syllogistic logic (mantiq) and philosophy ( falsafa). ${ }^{16}$

In sum, the difference between al-salafiyya as a substantive and madhhab al-salaf is not a mere technicality. Despite some overlap, the two concepts do not appear to share the same history and scope of meaning. Caution is thus in order when it comes to interpreting the term salafi prior to the 20th century. Because contemporary Salafism is generally conceived as a comprehensive orientation that embraces the entire gamut of religious beliefs and practices, we must be careful not to project this inclusiveness back in time. ${ }^{17}$ There is nonetheless a tendency in the scholarship to suggest that premodern Muslims recognized a distinct Salafi school of thought that informed not only theology but also law. ${ }^{18}$ However, this view of an all-encompassing Salafi Islam may reflect modern conceptualizations more than it does medieval typologies. This is not to deny that law and theology intersected - they did. Yet from a conceptual perspective it is telling that a Muslim's ascription to the salaf often entailed a distinction between the two. For example, Ibn Kathir (d. 1373), who was a disciple of Ibn Taymiyya in his youth, championed the madhhab al-salaf in creed but nonetheless considered himself a Shafi $\mathrm{i}$ in jurisprudence ( fiqh). He was not alone: his Tabaqat al-Fuqaha' al-Shaficiyyin lists other Shafi i jurists who conformed to the salaf in creed. ${ }^{19}$ Furthermore, there is ample evidence that madhhab al-salaf, along with the epithet "Salafi," referred to a theological rather than to a legal stance well into the 20th century. ${ }^{20}$ 
To be sure, there were 'ulama' who rejected the principle of legal schools, both before and after Ibn Taymiyya's time. The question is whether they viewed their legal methodology as constitutive of a specifically "Salafi" Islam or whether the sources allow us to assume that they did. The answer is not obvious and depends largely on the criteria used to build and justify knowledge about Salafism. For instance, does the existence of a statement in which al-Dhahabi (d. 1348) describes Ibn Taymiyya as a follower of "the Salafi way" (al-taríqa al-salafiyya) in legal matters constitute proof that a broad concept of Salafi Islam existed in the medieval period $?^{21}$ It is tempting to answer in the affirmative, as one scholar has. ${ }^{22}$ However, this interpretation rests on a number of implicit assumptions and inferences that require justification. Is al-Dhahabi's statement unusual in the medieval sources, or is it indicative of a broader trend? Is it as meaningful as it seems, or could it be translated in a conceptually neutral manner as "the ancestral way"? Is it inherently more significant than other expressions found in medieval texts, including "follower of the prophet Muhammad in law" (muhammadi al-madhhab) or "follower of the school of the people of hadith in fiqh" ( fi al-fiqh 'alā madhhab ahl al-hadìth)? $?^{23}$

The issue lurking behind these questions is that of conceptual anachronism. The very fact that contemporary scholars tend to single out Salafi epithets in premodern literature signals the possibility that conceptual predispositions are influencing the research and endowing certain medieval passages with more significance than they merit. It is doubtful that al-Dhahabi's statement would have attracted much attention had salafiyya not become a major concept in modern times. Of all the epithets and technical terms that medieval Muslims used to refer to themselves and their purist approach to Islamincluding ahl al-sunna (people of the Sunna), ahl al-hadith (people of hadith), and atharī (from athar, a term meaning "report," formerly interchangeable with "hadith"), many did not derive from the word salaf. Moreover, Salafi epithets were not necessarily the most popular. Contemporary Salafis often quote the biographical dictionary of alSam 'ani (d. 1166), in which there is a short entry for the surname "al-Salafi" (the Salafi), but they usually fail to mention that al-Sam 'ani was unfamiliar with the surname and could not list more than two unidentified individuals - a father and his son-who were reportedly known by it. ${ }^{24}$ By contrast, his entry for the surname "al-Athari" is replete with examples. ${ }^{25}$ Even Ibn Taymiyya, according to his foremost Western biographer, used the adjective muhammadi more frequently than he did salafi. ${ }^{26}$ How, then, did Salafi epithets come to prevail and acquire so much significance from the 1920s onward? One of the goals of conceptual history is precisely to explain why contemporary observers take Salafism rather than, say, Atharism as a self-evident category and object of study. We cannot reflect on the history and meaning of Salafism without first recognizing its status as a construct, a "quasi-character" whose story can be narrated. ${ }^{27}$

\section{SALAFI THEOLOGY AND ISLAMIC MODERNISM}

Until about the 1990s, the standard academic view held that the birth of this quasicharacter did not date from the medieval period but rather from the late 19th century. Although it takes various forms, the modernist narrative of Salafism usually builds on the idea that Jamal al-Din al-Afghani and Muhammad 'Abduh, following their exile in Paris in the 1880s, either created or spearheaded a reformist movement whose flagship 
journal was al-'Urwa al-Wuthqa (The Indissoluble Bond) and whose slogan was salafiyya.$^{28}$ For decades, this widely accepted belief served as the basic foundation for constructing the history of salafiyya as the history of Islamic modernism and its advocates. Hence, Western and Western-trained scholars often told the story of Salafism-its rise, evolution, and decline-in terms of the ideas and principles deemed representative of Islamic modernist reformism broadly conceived, including the rejection of blind imitation (taqli d), the promotion of rationality and progress, and the emancipation of women. ${ }^{29}$ Ultimately, one's degree of commitment to these ideas and principles-or to some of them-became a major criterion by which scholars determined who was a Salafi and who was not, regardless of theology. This level of conceptual looseness even made it possible to speak of "Salafi shi i ulama." 30

Although it long served as a paradigm, this conception of Salafism is flawed in many respects, especially because it is based on claims that remain unsubstantiated. The first known association between al-Afghani, 'Abduh, and a movement called "the salafiyya" appeared in 1919 in a short notice that French scholar Louis Massignon (d. 1962) wrote in Revue du monde musulman. Massignon did not initially claim that the two reformers founded the movement, but this idea gained momentum and found its formal expression in 1925, at which time Massignon added Rashid Rida to the narrative and presented him as the leader of the salafiyya. ${ }^{31}$ Since then, Massignon's narrative and its resulting typology have been reiterated in countless works through a chain of Western scholars who trusted each other's authority, thereby becoming one of the fundamental postulates on which the study of modern Islamic thought is based. Although it is true that alAfghani and 'Abduh provided the initial élan for a type of Islamic reformism that later became known as modernist Salafism, primary sources do not corroborate the claim that they either coined the term or used it to identify themselves in the late 19th century.

For example, neither salafiyya as a substantive nor any Salafi epithet (salafi, salafiyyün) is mentioned in al-'Urwa al-Wuthqa. Likewise, references to the salafiyya are conspicuously absent from the major obituaries of al-Afghani and 'Abduh, which further suggests that the two men never emphasized the concept. ${ }^{32}$ In actuality, the amount of time and energy required to find any Salafi epithet in the writings of alAfghani and 'Abduh is inversely proportional to their alleged status as proponents-and even founders - of Salafism. In 1902, three years before his death, 'Abduh made a very rare mention of the Salafis (al-salafiyyin) in the pages of al-Manar. Although he did not criticize them, he clearly did not claim to be one of them nor did he imply that the Salafis were his followers. Rather, he briefly presented them as Sunni Muslims who differed from the Ash'aris with respect to theology. The most striking feature of this passage, however, is that 'Abduh did not even expect his readers to know who the Salafis were. Evidently the word begged for an explanation, even among the subscribers of al-Manar, for 'Abduh deemed it useful to specify in parentheses that the Salafis were "people who adhere to the creed of the forefathers" (al-äkhidīn bi-'aqīdat al-salaf). ${ }^{33}$

Apart from the weight of scholarly tradition, there is little reason to consider al-Afghani and 'Abduh as self-proclaimed Salafis or proponents of a broad salafiyya movement. The fact that both men invoked the pious ancestors, as did many other Muslims before them, does not constitute a sufficient explanation and must not become a red herring. The danger here is to vindicate a problematic narrative of Salafism through post facto rationalization, that is, by attributing our own conceptual rationale to 
past Muslims. One may posit that they were Salafis because they took the salaf as role models for religious, social, and political reform, but such a conceptual declaration has yet to be found in the writings of the reformers. That said, there were individuals within the Islamic modernist network of Muhammad 'Abduh and Rashid Rida (especially in the urban centers of Iraq and Syria, where Hanbali theology had deeper historical roots) who used the Salafi epithets that had existed since the medieval period. ${ }^{34}$ These individuals belonged to a new generation of Muslim reformers who tapped the legacy of Ibn Taymiyya in order to challenge the political framework of the Ottoman Empire as well as its religious institutions and patronage of traditional 'ulama'. Some of these Salafis were more tolerant of theological diversity than their medieval predecessors, but they nonetheless abided by the madhhab al-salaf. On the whole, the meaning they ascribed to Salafi epithets remained within the semantic range of medieval Islamic literature. ${ }^{35}$

For example, the correspondence between Jamal al-Din al-Qasimi (d. 1914) in Ottoman Syria and Mahmud Shukri al-Alusi (d. 1924) in Ottoman Iraq-two of the most important Salafi scholars of the early 20th century-provides documentary evidence of the currency of Salafi epithets among them. One letter from al-Qasimi dated from 1909 mentions "the Salafi doctrine" (al-madhhab al-salafi ), and in many places the two scholars refer to themselves and their associates as Salafis (salafiyyūn). ${ }^{36}$ They conceived of the Salafis as a transnational community of past and present Muslims from all walks of life-scholars, businessmen, and rulers-who adhered to the Hanbali creed, focused on the scriptures, and deferred to the works of Ibn Taymiyya. In the most explicit passages of their correspondence, both al-Qasimi and al-Alusi continue to use Salafi epithets in a purely theological sense. While the former distinguishes the Salafis from the Jahmis and the Mu'tazilis, the latter describes a Moroccan scholar as "Salafi in creed and atharī in law" (al-salafì 'aqüdatan al-atharī madhhaban) ${ }^{37}$ It is interesting to note that this is how Rashid Rida first used and understood Salafi epithets as well. In 1905, he spoke of the Salafis (al-salafiyya) as a collective noun, in contradistinction with the Ash'aris (al-ash $\bar{a}^{\mathrm{c}}$ ira $){ }^{38}$ Although he and some of his disciples later declared themselves to be Salafis with respect to fiqh (in 1928 Rida even acknowledged his passage from being a Hanafi to becoming a Salafi), the available evidence suggests that the broadening of Salafi epithets to encompass the realm of the law was a gradual development that did not bloom in full until the 1920s. ${ }^{39}$

On empirical grounds, it is therefore difficult to support the claim that Salafi epithets initially referred to a broad movement of modernist reform. Rida, for one, did not consider that being a Salafi was sufficient to be counted among the proponents of the Islamic modernist school of thought (madrasa fikriyya) founded by al-Afghani and 'Abduh. ${ }^{40}$ The individuals who belonged to that movement, Rida claimed, were first and foremost notable for their commitment to modern reform (ișläh) and their sense of balance and moderation ( $i^{c} t i d \bar{a} l$ ), which inspired them to promote conciliation between Islam and the political, social, and scientific achievements of Western civilization. ${ }^{41}$ In other words, Islamic modernism was a moderate approach to Islam because it struck a balance between reason and revelation, thus arriving at a middle ground between blind following of the West on the one hand and Islamic conservatism on the other. Being Salafi of creed may have been laudable and beneficial, but it neither entailed nor automatically paved the way for a moderate or modernist approach. This is why, in 1905, Rida casually referred to the Wahhabis as Salafis (al-wahhābiyya al-salafiyya): 
such a statement was not an oxymoron nor did it imply that the Wahhabis were, or could be, advocates of Islamic modernism. ${ }^{42}$ In 1913, Jamal al-Din al-Qasimi also voiced his disappointment that the people of Najd-where he considered Salafi theology to be the most widespread-were too conservative. The Wahhabis were overcome with harshness $(j a f \bar{a})$ and exaggeration ( $g h u l \bar{u})$, he wrote; they were not "moderate" like the other Salafis in Iraq, the Hijaz, Greater Syria, and Egypt. ${ }^{43}$

The confusion between Salafi epithets and Islamic modernism, which is still common in scholarly literature, is nonetheless understandable. Many of the Islamic modernists whom Rida singled out in al-Manar also happened to follow the doctrine of the forefathers and were introduced as such. Chief among them were Jamal al-Din al-Qasimi and Tahir al-Jaza'iri (d. 1920), a fellow Syrian reformer from Damascus who lived in Egypt for several years. To varying degrees, these scholars were Salafis with respect to theology, but, more important, they espoused progressive and modernist ideas. ${ }^{44}$ There were many other Salafis-cum-modernists, but al-Qasimi and al-Jaza'iri deserve a special mention here because the founders of the Salafiyya Bookstore were among their pupils. The name of this institution would dramatically increase the impression that salafiyya and Islamic modernism were synonymous.

\section{MUHIBB AL-DIN AL-KHATIB AND THE SALAFIYYA BOOKSTORE}

The original Salafiyya Bookstore (al-Maktaba al-Salafiyya), established in Cairo in 1909, was at once a symbol and an agent of the growing popularity of Salafi epithets. The main figure behind this institution was Muhibb al-Din al-Khatib, the well-known Damascene activist who became a household name in the Egyptian publishing business. Born in 1886, al-Khatib epitomized the versatility of Arab elites in the last decades of the Ottoman Empire. He also embodied the overlap between Salafi inclinations and Islamic modernism. Al-Khatib first received a traditional education at the hands of his father, who was a prominent religious scholar of Damascus, and then attended the city's top secondary school, Maktab 'Anbar, where he learned modern sciences, Ottoman Turkish, French, and some Persian. ${ }^{45}$ As a cosmopolitan youth, al-Khatib also studied in a state school in Beirut, moved to Istanbul between 1905 and 1907, and then worked as a translator for the British consulate in Yemen before settling down in Egypt. During these formative years, he became fully dedicated to the renaissance (nahda) of Arab culture and the revival of Arab political power within a decentralized Ottoman framework. His work-as a writer and, later on, as a publisher-stemmed from the same sense of activism.

His involvement in cultural and political affairs, however, never contradicted or even diminished his devotion to Islam and his reliance upon the guidance of Salafi-cummodernist 'ulama'. An orphan by the age of thirteen, al-Khatib developed a close relationship with the Salafi scholar Tahir al-Jaza'iri, who became his mentor and spiritual father. ${ }^{46}$ In Damascus, al-Jaza'iri not only advised his pupil to pursue a modern secular education but also encouraged him to keep seeking religious knowledge. Therefore, al-Khatib studied under Jamal al-Din al-Qasimi and other local Salafi scholars. ${ }^{47} \mathrm{Al}-$ Jaza'iri, for his part, kept al-Khatib under his wing and introduced him to the literary treasures of the Zahiriyya library, of which he was the founder and curator. Al-Jaza'iri even hired his pupil to read and transcribe a number of old manuscripts, including parts of the oeuvre of Ibn Taymiyya. ${ }^{48}$ Thus, al-Khatib grew familiar with the Islamic reformist 
heritage while keeping up with the stimulating literary output of the renaissance and reform movements. Like Rida and many fellow modernists, he was an avid reader of the journals al-Hilal and al-Muqtataf, which were neither Islamic nor religious per se but boasted progressive Muslim contributors such as Husayn al-Jisr, Shakib Arslan, and Muhammad Kurd 'Ali. ${ }^{49}$ At the same time, al-Khatib did not fail to peruse al-Kawakibi's seminal book Umm al-Qura, Muhammad 'Abduh's analysis of Islam and Christianity, as well as 'Abduh's response to the criticisms that French historian and statesman Gabriel Hanotaux had leveled against Islam. ${ }^{50}$

Briefly put, al-Khatib's background and interests blended Islamic scholarship with the various facets of the reformist and modernist trends. This synthetic approach infused his work, and the opening of the Salafiyya Bookstore afforded him the opportunity to spread it under the label salafiyya. His partner in this endeavor, 'Abd al-Fattah Qatlan, was the maternal cousin of a Damascene shaykh named Mustafa al-Qabbani (d. 1918). Al-Khatib met Qatlan during a short stopover in Cairo in late 1907, as he was bound for Yemen. Qatlan was staying in a house with his uncle and Tahir al-Jaza'iri, who had just immigrated to Egypt. When al-Jaza'iri offered hospitality to al-Khatib, the latter became acquainted with his future associate and brother-in-law. ${ }^{51}$

The foundation of the Salafiyya Bookstore took place two years later, when al-Khatib returned from Yemen. With the help of Qatlan, he used the money earned from the sale of a house he owned in Damascus to establish the bookstore in Khan al-Khalili, across from the Husayn mosque. Al-Khatib, who was evidently the more prominent member of the duo, soon began working in the morning as an editor for 'Ali Yusuf's famous

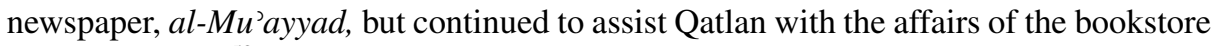
in the afternoon. ${ }^{52}$ It is not clear how long it took for the bookstore to generate profits, but al-Khatib did not mind taking up a second job that provided him with a steady income, greater visibility, and useful contacts in the printing business. Indeed, the Salafiyya Bookstore did not, at first, print its own material. Al-Khatib and Qatlan selected a number of recent and old texts and used the services of local printing presses such as Matba'at al-Nahda and, more often, Matba'at al-Mu'ayyad. The Salafiyya Bookstore then either paid for the impression or used grants and donations from individual patrons. Once printed, the books were stocked and sold directly at the bookstore or shipped to customers by mail for an extra fee. ${ }^{53}$ In addition to printed material, the bookstore also carried manuscripts. ${ }^{54}$

One of the primary goals of al-Khatib and Qatlan was to satisfy the desires of educated Arab readers who sought to rediscover their religious, historical, and cultural heritage with an eye to the advancement of their society. Although the progressive nature of Islam was a recurring theme in its publications, the Salafiyya Bookstore touched upon a wide range of issues that were not always connected to religious renewal per se. According to its own advertisement, the bookstore's mission was to render books on religion, science, literature, history, and society available to the public. Because of its name, however, the Salafiyya Bookstore willy-nilly intertwined the term salafiyya with the elevation of Arabs and Muslims in the modern world. In other words, al-Khatib and Qatlan expanded the scope of this adjective well beyond its original theological meaning and associated it with a broad and multifaceted reformist program. If we are to believe al-Khatib, this development was not unbeknown to Salafi scholars, for the idea of naming the bookstore "Salafiyya" came from no other than his mentor, Tahir al-Jaza'iri. The latter had such 
esteem for the madhhab al-salaf and was so devoted to its revival that he reportedly advised al-Khatib and Qatlan to name their business after it. ${ }^{55}$ Whether this is true or not, it is possible that the two young men misinterpreted the term. In the early 1910s, Jamal al-Din al-Qasimi lamented that many people in his entourage, including journalists, knew nothing of the salaf but the name and were unable to distinguish Salafis from non-Salafis. 56

In any event, this appears to be the first time salafiyya was ever used as a slogan for commercial purposes. Under this label, al-Khatib and Qatlan sold books that were obviously not selected on the basis of their theological stringency. In addition to treatises on grammar by al-Suyuti (d. 1505) and Ibn Faris al-Qazwini (d. circa 1005), the bookstore marketed literature on Arabic proverbs and the science of hadith by Tahir al-Jaza'iri. It also reedited the works of medieval Muslim philosophers, including a treatise by al-Farabi (d. 950) and two epistles by Ibn Sina (d. 1037) on phonetics and logic. ${ }^{57}$ In the 1910s, it is clear that when al-Khatib and Qatlan spoke of the "forefathers," they were not using the term in its narrower religious sense. They had enough business flair to place virtually any medieval homme de lettres, including Ibn Sina, among the salaf..$^{58}$

The reason al-Khatib and Qatlan chose to revive the works of towering philosophers and logicians was unequivocal: they sought to underline the Muslims' past grandeur and contribution to the emergence of modernity in the West. ${ }^{59}$ They also strove to bridge the gap between the Muslim world and the West by arguing that the former was on a par with the latter. ${ }^{60}$ Overall, the type of literature that the bookstore promoted in the early $1910 \mathrm{~s}$ was in perfect harmony with the themes and concerns that are now considered typical of modernist Salafism. Despite its name, however, the bookstore did not emphasize Salafi theology. Instead, al-Khatib and Qatlan focused on the rationality and dynamism of Islam and Muslim societies. They did not consciously attempt to mold or redefine the adjective salafiyya into a concept under which the various facets of Islamic modernism would fall. Yet, because their commercial venture used salafiyya as a slogan, it tended to suggest a fundamental link between that term and the religious, historical, social, political, and linguistic issues they promoted. Moreover, given the connections of al-Khatib and Qatlan, it did not take long before the label salafiyya spread. Within a year of its creation, the Salafiyya Bookstore received praise-and therefore publicity-from journals such as al-Manar, al-Hilal, and al-Muqtataf in Egypt and al-Muqtabas in Syria. ${ }^{61}$

\section{LOUIS MASSIGNON AND THE SALAFYAH REVIEW}

In 1912, al-Khatib and Qatlan seized the opportunity to go into business with Rashid Rida. The Salafiyya Bookstore relocated from Khan al-Khalili to 'Abd al- 'Aziz Street to join the famous Manar Bookstore (Maktabat al-Manar), of which al-Khatib and Qatlan briefly became co-proprietors $(a, \underline{h} \bar{a} b) .{ }^{62}$ Because the Salafiyya Bookstore often operated under the name of al-Manar, it seems to have escaped the attention of most Orientalists at first. However, its growth in the second half of the 1910s did not go unnoticed and even propelled the label salafiyya into the European scholarly jargon. This took some time because World War I disrupted the activities of the Salafiyya Bookstore. In addition to his involvement in political societies and his work as an author, journalist, and teacher, the overcommitted al-Khatib traveled extensively during the war and was even imprisoned in Basra for seven months. In the summer of 1916, he moved to the Hijaz at the invitation 
of Sharif Husayn, the amir of Mecca, who had just launched the Arab Revolt. Al-Khatib became the amir's chief journalist and spokesperson. He established a state printing press named al-Matba'a al-Amiriyya, published books on modern sciences and crafts, and edited the biweekly newspaper al-Qibla ${ }^{63}$ During his stay in the Hijaz from 1916 to 1919 , al-Khatib thus gained valuable experience in the field of printing.

Although some of the details surrounding al-Khatib and Qatlan in this period are obscure, it appears that the former applied his Hijazi experience to the still existing Salafiyya Bookstore in Egypt. Despite his prolonged absence from Cairo, al-Khatib did not sever his ties to Qatlan, who continued managing the business. In the face of wartime inconveniences and unforeseen difficulties, the bookstore underwent significant changes in the late 1910s. Its owners acquired a printing press, and by 1919 they were independent and had started printing their own material. Another clear marker of their successful expansion was the formal name change in 1917, when the Salafiyya Bookstore became the Salafiyya Bookstore and Journal (al-Maktaba wa-l-Majalla al-Salafiyya). The change referred to the short-lived monthly reformist journal, al-Majalla al-Salafiyya, created and edited by Qatlan, which he rendered into English as the Salafyah Review (the spelling is his) and for which Tahir al-Jaza'iri was a consultant. ${ }^{64}$

This journal served as a promotional vehicle for reviving the bookstore and reaching a wider readership. It provided an additional outlet for publishing proofed manuscripts and various studies, most of which pertained to linguistics, literature, and astronomy. According to Qatlan, one of the journal's purposes was to propagate the achievements (ma'äthir) of the pious ancestors, but few articles dealt with religious topics per se. ${ }^{65}$ The only text published under the title "Influence of the Ancients on the Moderns" (Athar al-Salaf fī al-Khalaf) was the translation of a passage from Gustave Le Bon's 1898 book, Lois psychologiques de l'évolution des peuples (Psychological Laws of the Evolution of Peoples). ${ }^{66}$ Overall, the content of the Salafyah Review was in direct line with the original raison d'être of the Salafiyya Bookstore. Relevant examples of its progressive and modernizing goals can be found in the scientific almanac (taqwīm 'ilmī) published in early 1918 in lieu of the eleventh and twelfth issues. Not only did the almanac aim at introducing readers to astronomical and geographical sciences for both religious and profane purposes but also it displayed a clear openness toward the West and promoted interfaith dialogue and coexistence within the context of the Egyptian state. For instance, the relatively complex chart that provided the specific time for each Muslim prayer on each day of the year included corresponding entries based on the Gregorian and Coptic calendars. It also made mention of Jewish holidays. ${ }^{67}$ In other sections, the almanac aimed at reviving the scientific heritage of Islamic civilization while trying to teach readers about the Western calendar system and its mathematical rationale.

Although it only lasted two years, the journal played a significant role in spreading the label salafiyya overseas. In Paris, the first issue of the Salafyah Review reached the office of the leading journal Revue du monde musulman, to which Louis Massignon was a major contributor. In the previous decade, Massignon had begun subscribing to a large range of Arabic journals in order to provide the readers of the Revue with a review of such literature. ${ }^{68}$ The task of analyzing the Salafyah Review, however, fell to another Orientalist, Lucien Bouvat, who in 1918 reflected favorably on the eclectic and enlightening approach of this intriguing journal from Cairo. ${ }^{69}$ Still, it is obvious that Bouvat could not make sense of the journal's title, either in the original Arabic 
or in the English rendition provided on the top cover. Because the title derived from the verb salafa (to precede), Bouvat naively translated al-Majalla al-Salafiyya as "the Retrospective Review" (La Revue rétrospective). To be sure, salafiyya meant nothing specific to him. Despite his familiarity with modern Islamic movements and ideas, he did not recognize this unusual term as a religious concept or even a slogan.

As if he had hoped to rectify Bouvat's honest mistake, Massignon tackled the problem as soon as he returned to Paris in 1919. The explanations he provided in Revue du monde musulman, however, proved just as misleading. Massignon argued that "the Salafiyah" was an intellectual movement that emerged in early 19th-century India at the time of Sayyid Ahmad Barelwi (d. 1831). Siddiq Hasan Khan (d. 1890), the founder of the Ahl-i Hadith movement, had later rehashed its ideas and "from there, [the Salafiyah] was spread by Jamal al-Din al-Afghani and Shaykh 'Abduh and established itself in Baghdad, Damascus, Cairo, and even in the Maghrib and Java."70 However, Massignon did not hold to this peculiar narrative for very long. Between 1920 and 1925, he dropped the references to colonial India and the early 19th century and linked salafiyya even more intimately to al-Afghani and 'Abduh. He sometimes defined the term as a group of Islamic modernists who called for reform and sometimes as a transnational movement of Islamic modernism founded in the late 19th century.

It is not clear why Massignon suddenly chose to focus on this word. Although his logic may be inscrutable, circumstantial evidence suggests that the emergence of the Salafyah Review on the European scene served as a catalyst for his conceptual elaboration of salafiyya as a modernist reform movement. At the time, Massignon was preparing a course on the Arabic press, which he first taught at the Collège de France in Paris in the fall of 1919, and he was clearly interested in formulating a typology that would allow him to distinguish the views of the Wahhabis from those of moderate reformers and journalists. ${ }^{71} \mathrm{He}$ had the intuition to realize that the title of the Salafyah Review was significant and could serve as a category for analyzing the modernist reform movement that some previous Orientalists had called "neo-Islam" and had described as neither fully Mu tazili nor fully Wahhabi. ${ }^{72}$ It is interesting that this idea had not occurred to him earlier. Massignon had known of the Salafiyya Bookstore since 1910, but his reviews of Arab reformist literature and journals_-including al-Manar-made no reference to a religious orientation called the salafiyya until $1919 .{ }^{73}$ This should come as no surprise, given that the concept is so elusive in al-Manar that it does not even figure in its index.

How Massignon formulated his undocumented historical claims is also enigmatic. Sources do not confirm whether he encountered Salafi epithets as early as 1908, when he traveled to Iraq and befriended the Salafi scholars Mahmud Shukri al-Alusi and his cousin, Hajj 'Ali al-Alusi (d. 1922). However, we know that Massignon studied Islam and Muslim societies with both of them in Baghdad and that he maintained subsequent correspondence with them. He also exchanged letters with Jamal al-Din al-Qasimi in Damascus and was fully aware of the two al-Alusis' relationship with both Rashid Rida and Siddiq Hasan Khan. ${ }^{74}$ In short, it is likely that Salafi epithets were not unknown to him. He knew some of the most influential Muslim scholars who were using them in the early 20th century and knew not only the links between these individuals but also their intellectual pedigrees. When the Salafyah Review caught the attention of Western scholars, Massignon may well have constructed his narrative of salafiyya by making a series of seemingly plausible but nonetheless untenable connections. 
Despite its factual and conceptual shortcomings, Massignon's new typology was convenient and seemed sensible. Several influential scholars welcomed such a timely contribution and took its validity for granted. In 1921, Harvard-educated writer Lothrop Stoddard repeated and further misinterpreted Massignon's earliest reference to the salafiyya in The New World of Islam, which, once translated into Arabic, became a bestseller in the Middle East. ${ }^{75}$ In 1922, the Hartford Seminary's journal The Moslem World translated an article from the Revue du monde musulman in which Massignon discussed "the writers known as Salafiyah."76 Besides the Belgian Jesuit Henri Lammens, Henri Laoust was the scholar most responsible for spreading Massignon's theories in French. In his seminal 1932 article, Laoust introduced the substantive "Salafism" (salafisme) and based his entire conceptual framework on Massignon's assumption that salafiyya was at once a slogan created by al-Afghani and 'Abduh and a group of Islamic modernists who pushed for a multifaceted reformist program. ${ }^{77}$ When Sir Hamilton Gibb relied on this article for his influential Modern Trends in Islam, the same ideas came to pervade English-speaking scholarship as well. ${ }^{78}$ Today, most definitions of Salafism as a movement of Islamic modernism can be traced back to Massignon through such chains of transmission. ${ }^{79}$

\section{SALAFISM AND ITS AMBIGUITY IN THE 1920S}

Although there is evidence that Massignon's conception of the salafiyya filtered back into the Middle East, there is no indication that his ideas and choice of words stirred any debate. ${ }^{80}$ In the Arabic version of Stoddard's The New World of Islam, for example, the passage about salafiyya did not elicit any reaction from the polemical Shakib Arslan (d. 1946), whose lengthy commentaries on other passages doubled the size of the book. The so-called Prince of Eloquence, who was not a religious expert per se, stood strangely mute in the face of Stoddard's confused description of the Salafi movement as a fanatical trend dominated by dervishes ${ }^{81}$ For all their oddities, both Stoddard's glaring errors and Arslan's silence reflect the lack of clarity about salafiyya in the 1920s, when the notion was being worked out simultaneously in the West and the Muslim world.

Whether or not Massignon influenced certain Arab intellectuals who knew his work or were among his friends, the growing visibility of Salafi epithets in various Muslim countries had prepared the ground for the endogenous construction of Salafism as a full-fledged concept. By the end of the 1920s, the substantive salafiyya had entered the religious literature and had evidently become a subject matter in its own right. One clear example is the title under which a Damascus-based entrepreneur published a letter written by Yusuf al-Dijwi (d. 1946), the famous antireformist scholar from alAzhar. Released as a booklet in January 1930, the letter was given the title A Word on Today's Salafism (Kalima fī al-Salafiyya al-Hādira). Although it leaves no grammatical doubt about the use of the substantive "Salafism," the choice of this title reveals a fair amount of conceptual ambiguity. First, nowhere in the text does al-Dijwi refer to the term salafiyya. The letter is critical of various trends of Islamic reformism, but the publisher does not explain why he chose to lump them all under "Salafism." Moreover, there is no evidence that al-Dijwi played any role in selecting the title under which his letter was published. Second, the letter treats both theology and legal methodology, thus suggesting that Salafism (al-salafiyya) was-at least in the mind of the Damascus-based 


\section{Henri Lauzière}

publisher-different from, and broader than, the traditional conception of the doctrine of the forefathers (madhhab al-salaf). Third, the letter provides no clear picture of who the proponents of Salafism were. On the one hand, al-Dijwi targets the blind followers of Ibn Taymiyya in general, whom he describes as utterly ignorant and inimical to other believers. He even accuses them of being descendants of the Kharijis because of their propensity to excommunicate fellow Muslims. On the other hand, al-Dijwi specifically criticizes Muhammad 'Abduh for his fascination with Europe, though the latter hardly qualified as a blind follower of Ibn Taymiyya. He also deprecates the religious views of the late 'Abd al-Baqi Surur Na im (d. 1929), a close associate of Muhibb al-Din al-Khatib and professor at al-Azhar who was neither an obscurantist nor a latter-day Khariji despite his fervent admiration for Ibn Taymiyya. ${ }^{82}$

Conceptual ambiguity was not unique to those who disparaged Salafi labels, however. Al-Khatib and Qatlan, who were not only publishers but also intellectuals, did not feel the need to explain or define the name of their bookstore and journal; after all, vagueness served them well. Their business ventures of the 1920s did nothing to clarify matters. When al-Khatib returned to Cairo in late 1920, after a year in Syria supporting Faysal's Arab Kingdom, he revived the Salafiyya Bookstore and its printing press, which had slowed down considerably after 1919. The institution moved to Bab al-Khalq near Dar al-Kutub and took on its final and most famous name: the Salafiyya Press and Bookstore (al-Matba a al-Salafiyya wa-Maktabatuha). ${ }^{83}$ From then on, its success was palpable. It published major works, inundated the market with its literary output, superseded many of its competitors in the publishing industry, and turned salafiyya into a commonplace term among the producers and consumers of Arabic books throughout the Middle East and beyond. So ubiquitous was the company's reputation that 'Ajjaj Nuwayhid (d. 1982), the Lebanese-Palestinian translator of Stoddard's The New World of Islam, wrote in his memoirs that al-salafiyya was more than the name of a publishing house: it also served as a slogan $\left(s h i^{`} \bar{a} r\right)$ for the entire movement that sought to revive the Arab-Islamic heritage and the memory of the pious ancestors. ${ }^{84}$

But this judgment, made in hindsight in the 1970s, oversimplifies history and semantics. In the 1920s, the very idea that salafiyya could stand for a multifaceted movement of revival and reform was still in its infancy. Moreover, the editing choices of the Salafiyya Press and Bookstore now displayed sufficient ambivalence to confuse some readers as to what kind of religious revivalism the term salafiyya actually conveyed. Although al-Khatib and Qatlan did not stop promoting Islamic modernism, they often printed and distributed literature that contradicted the most rationalist and liberal ideas of the reform movement. It is well known, for instance, that the strongest responses to 'Ali 'Abd alRaziq's secular understanding of Islam, as well as Taha Husayn's highly controversial work on pre-Islamic poetry, were published at the Salafiyya Press and Bookstore.

Al-Khatib and Qatlan's willingness to recalibrate the scope and meaning of Islamic modernism must be understood in the context of the mid-1920s. The fall of the Ottoman Empire, the establishment of the Mandate territories, and the abolition of the caliphate had made the fragility of the umma painfully obvious. Under these circumstances, many influential reformers, including Rashid Rida, turned toward religious conservatism and chose to throw their weight behind the young Saudi state, which offered hope of social and political renaissance in the Muslim world. Al-Khatib adopted this stance. In an era of widespread foreign occupation, he showed deference to the 
Wahhabis and became an unconditional supporter of the Saudi state, which he defended to the best of his journalistic abilities. These religious and political convictions were reflected in the activities of the Salafiyya Press and Bookstore. By 1924, the Saudis had already commissioned the publication of medieval Hanbali texts from al-Khatib and Qatlan. ${ }^{85}$

Nothing captures this evolution better than the establishment of a Salafiyya Press and Bookstore in Mecca that complemented the one in Cairo. It was not an independent venture but rather a franchise that Qatlan cofounded in partnership with a Hijazi notable named Muhammad Salih Nasif (d. 1971), who came from a prominent family of Jeddah and had previous experience in the publishing business. ${ }^{86}$ Together, Qatlan and Nasif bought an old printing press from Rashid Rida in Cairo and shipped it to Mecca in 1927, where it became the cornerstone of the Saudi branch of the Salafiyya Press and Bookstore. ${ }^{87}$ The branch began operating in 1928 and specialized in Hanbali and proWahhabi books that suited local patrons. Its first publications included a theological treatise by Ibn Qayyim al-Jawziyya, whose printing was requested and paid for by Ibn $\mathrm{Sa}^{\mathrm{c}} \mathrm{ud}$, as well as a reedition of the standard pro-Wahhabi history of Najd by Ibn Bishr. ${ }^{88}$

By expanding his business with the Saudi state and catering to the taste of its political and religious elite, Qatlan contributed to bringing his commercial label closer to Wahhabism. This is not to say that the Saudis became the sole trustees of the label or that salafiyya immediately lost its modernist flavor. At times, the original Salafiyya Press and Bookstore in Cairo still published on topics that Wahhabi scholars regarded with suspicion. In 1929, when Qatlan and Nasif were about to publish a Hanbali commentary on the Salafi creed in Mecca, al-Khatib released a dissertation on René Descartes in Cairo. ${ }^{89}$ This book supplemented a series of informative studies available since the mid1920s on topics ranging from women's emancipation to Raja Yoga to Ibn Rushd. ${ }^{90}$ None of these publications originated from the Saudi franchise, though written advertisements insisted that all the material sold at the Cairo branch could be requested in Mecca as well. ${ }^{91}$ Still, purist considerations often prevailed over the open-mindedness of the early 1910s. In 1932, Henri Laoust was indeed struck by the rise of "neo-Hanbalite Puritanism" within the Salafi reformist program. ${ }^{92}$ The fact that he perused the latest catalogue of the Salafiyya Press and Bookstore to gauge the evolution of Salafism-a concept that he was simultaneously constructing and studying-could only reinforce that impression. ${ }^{93}$

It is obvious that redefinitions and counter-definitions of Salafi epithets were unavoidable. Yet the popularization and successful commodification of the adjective salafiyya were bound to bring the purist and theological roots of the word back to the fore. Given that al-Khatib and Qatlan had no monopoly over their marketing slogan, and given that the intellectual connection between salafiyya and al-Afghani and 'Abduh was largely unfounded, it was only natural for exponents of Islamic purism to take advantage of the label without promoting any modernist agenda. In 1921, a Salafiyya Bookstore existed in Multan, in present-day Pakistan, run by a man named 'Abd al-Tawwab al-Multani (d. 1947), who was close to both the Ahl-i Hadith movement in India and the Wahhabis in Najd. ${ }^{94}$ In 1922, another Salafiyya Bookstore was in operation in Damascus. Its principal owner, Muhammad Ahmad Dahman (d. 1988), was a student of the Syrian Hanbali scholar Ibn Badran (d. 1927), both of whom were known for their collaboration with the Saudis. ${ }^{95}$ By the early 1930 s, a small pietistic group dedicated to the eradication 
of innovations, known as The Salafi Association (al-Jam iyya al-Salafiyya), also existed in Giza, near Cairo. ${ }^{96}$

\section{CONCLUSION}

Unlike intellectual genealogies, conceptual history focuses on the emergence and construction of the notion of Salafism and raises a fundamental epistemological question: how do we know what we know (or what we think we know) about salafiyya? By showing how past scholars have shaped the concept as a quasi-character with a chronological origin and distinctive personality traits, this approach makes it easier to pinpoint significant sources of confusion about the history and meaning of Salafism and Salafi epithets. On the one hand, although the purist conception of Islam that is now subsumed under the substantive salafiyya has clear medieval origins, it is far from certain that the concept itself existed prior to the 20th century. If it did exist, it must have been highly unusual. To be sure, Salafi epithets (adjectives and nouns other than the substantive salafiyya) sometimes appeared in religious literature, at least from the 12th century onward. However, they were, on the whole, more restricted in meaning than they later became. In many cases, they referred to a purely theological stance. Given the lack of empirical support, it would be presumptuous and ahistorical to equate the doctrine of the forefathers (madhhab al-salaf) with the broader concept of Salafism (al-salafiyya) that now commands so much attention and often encompasses theology, law, morals, and etiquette.

On the other hand, the belief that Jamal al-Din al-Afghani and Muhammad 'Abduh spearheaded a movement of Islamic modernism called salafiyya in the late 19th century relies on assumptions rather than evidence. Contrary to conventional wisdom, and despite numerous attempts to portray these two men as Salafis after the fact, there is still no proof that they ever promoted Salafi epithets, used the substantive salafiyya, or conceptualized a religious orientation of that name. Conversely, there is evidence that Louis Massignon created this narrative and its resulting typology in the early 20th century through a series of unsubstantiated assertions. Many academics trusted these arguments of authority from the outset and have repeated them ever since, thereby wrongly conflating salafiyya and modern ișlāh. Until an indigenous version of this narrative predating 1919 is discovered, we cannot rule out the possibility that Massignon's influence extended to the Middle East and North Africa as well.

The construction of Salafism cannot be understood separately from the effervescent print culture of the early 20th century. Massignon's theories on the origins and meaning of salafiyya coincided with the diffusion of the modernist journal al-Majalla al-Salafiyya, or the Salafyah Review, on the European scholarly scene. The commodification of the adjective salafiyya and its use as a marketing tool, which began in 1909 with the foundation of the Salafiyya Bookstore, played a key role in popularizing the label, thus contributing to its mutation into a major concept in the West and in the Muslim world from the 1920s onward. This still does not validate the widely accepted but weak premise that early 20th-century Muslim activists already recognized salafiyya as the name of a multifaceted movement of reform. Leading reformist 'ulama' did combine Salafi theology with an unmistakable concern for the progress of Muslim societies in the modern era; yet it was the success of salafiyya as a label to market the reformists' 
literary output that formally blurred the distinction between the theological doctrine of the forefathers and the modernist agenda for which the salaf served as role models. In other words, modernist Salafis did exist in the late 19th and early 20th centuries, but they were not proponents of "modernist Salafism." Rather, they were proponents of Islamic modernism who happened to be Salafi of creed.

Although al-Khatib and Qatlan had no intention of creating or shaping a concept, some observers construed their editing choices and criteria of publication as indications of the defining characteristics of what came to be known as Salafism. When the Salafiyya Press and Bookstore along with other reformist publishers such as the Manar Press started supporting the Saudi state and collaborating with its elite from the 1920s onward, French scholar Henri Laoust could not help but conclude that Salafism was shifting away from Islamic modernism. The impression that some progressive intellectual entity called Salafism turned into Wahhabism or gave way to a "neo-Salafiyya" 97 is thus not new but remains as misleading as the conceptual postulates on which it rests. The reification of early 20th-century Salafism as an intrinsically modernist movement of reform is a figment of scholarly imagination that cannot withstand historical scrutiny. In the Muslim discourses of the 1920s, al-salafiyya was at best a nascent conceptual construct and was already too ambiguous to be pinned down.

\section{NOTES}

Author's Note: I am grateful to Princeton University's Department of Near Eastern Studies and its postdoctoral fellowship program for providing me with the opportunity to complete this project.

${ }^{1}$ Bernard Rougier, ed., Qu'est-ce que le salafisme? (Paris: Presses Universitaires de France, 2008); Roel Meijer, ed., Global Salafism: Islam's New Religious Movement (New York: Columbia University Press, 2009). The latter volume includes a noteworthy chapter by Bernard Haykel.

${ }^{2}$ Emad Eldin Shahin, "Salafiyah," in The Oxford Encyclopedia of the Islamic World, ed. John L. Esposito (New York: Oxford University Press, 2009), 5:28-35; Édouard Méténier, "Que sont ces chemins devenus? Réflexion sur les évolutions de la salafiyya irakienne de la fin du XVIIIe au milieu du XXe siècle," in $L e$ courant réformiste musulman et sa réception dans les sociétés arabes, ed. Maher al-Charif and Salam Kawakibi (Damascus: Institut Français du Proche-Orient, 2003), 85-113; Uwaidah M. Al Juhany, Najd Before the Salafi Reform Movement: Social, Political, and Religious Conditions During the Three Centuries Preceding the Rise of the Saudi State (Reading, U.K.: Ithaca Press, 2002); Ibrahim M. Abu-Rabi ${ }^{c}$, Contemporary Arab Thought: Studies in Post-1967 Arab Intellectual History (London: Pluto Press, 2004), 65-72. Abu-Rabi` based his analysis on the works of Arab intellectuals who use Salafism very loosely. For a typical example with respect to Moroccan history, see 'Abd al-Jalil Baddu, al-Salafiyya wa-l-Islah (Tangier, Morocco: Siliki Ikhwan, 2007).

${ }^{3}$ For a review of this problem in European intellectual history, see Tore Frängsmyr, À la recherche des Lumières: une perspective suédoise, trans. Jean-François Battail and Marianne Battail (Bordeaux, France: Presses Universitaires de Bordeaux, 1999), 13, 16-22. The expression "Renaissance Enlightenment" comes from Ira O. Wade, The Intellectual Origins of the French Enlightenment (Princeton, N.J.: Princeton University Press, 1971).

${ }^{4}$ P. Shinar and W. Ende, "Salafiyya," in Encyclopaedia of Islam, 2nd ed. (hereafter $E I^{2}$ ) (Leiden: E. J. Brill, 1960-2005). This subnarrative continues to inform contemporary studies. See Mahmoud Haddad, "The Manarists and Modernism: An Attempt to Fuse Society and Religion," in Intellectuals in the Modern Islamic World: Transmission, Transformation, Communication, ed. Stéphane A. Dudoignon, Komatsu Hisao, and Kosugi Yasushi (London: Routledge, 2006), 55-73. Outside of Western scholarship, see Muhammad 'Imara, al-Imam Muhammad 'Abduh: Mujaddid al-Dunya bi-Tajdid al-Din (Beirut: Dar al-Wahda li-l-Tiba'a wa-1-Nashr, 1985), 87-88; and 'Allal al-Fasi, "al-Haraka al-Salafiyya fi al-Maghrib," in Durus fi al-Haraka alSalafiyya: al-Mashriq wa-l-Maghrib al- 'Arabi, ed. Muhammad Fa`iq et al. (Casablanca, Morocco: Manshurat 'Uyun, 1986), 129. 
${ }^{5}$ Madawi Al-Rasheed, Contesting the Saudi State: Islamic Voices from a New Generation (Cambridge: Cambridge University Press, 2007), 3; Bernard Haykel, "On the Nature of Salafi Thought and Action," in Global Salafism, ed. Meijer, 34, 45-47; Arnaud Lenfant, "L'évolution du salafisme en Syrie au XXe siècle," in Qu'est-ce que le salafisme?, ed. Rougier, 161-178.

${ }^{6}$ Muhammad Sacid Ramadan al-Buti, al-Salafiyya: Marhala Zamaniyya Mubaraka la Madhhab Islami, 2nd ed. (Damascus: Dar al-Fikr, 1998), 234-35.

${ }^{7}$ Muhammad 'Imara, al-Salafiyya (Sousse, Tunisia: Dar al-Ma'arif li-1-Tiba'a wa-1-Nashr, n.d.), 12-16; Rougier, ed., "Introduction," in Qu'est-ce que le salafisme?, 7-12.

${ }^{8}$ Haykel, "On the Nature of Salafi Thought," 38.

${ }^{9}$ Meijer, ed., "Introduction," in Global Salafism, 4.

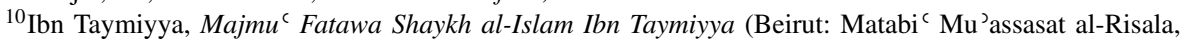
1997), 33:177. In this passage, Ibn Taymiyya first discusses how the Jahmis (al-jahmiyya) misinterpreted the attributes of God and then examines how another group, the Salafis (al-salafiyya), had a correct understanding. For similar examples, see Ibn Taymiyya, Majmu ' Fatawa, 6:379; idem, Dar' Ta 'arud al- 'Aql wa-l-Naql, ed. Muhammad Rashad Salim (Riyadh: Jami 'at al-Imam ibn Sa 'ud al-Islamiyya, 1980), 2:8; and idem, Bayan Talbis al-Jahmiyya fi Ta'sis Bida'ihim al-Kalamiyya (n.p.: Mu'assasat Qurtuba, 1980), 1:122.

${ }^{11}$ Ibn Taymiyyah, Ibn Taymiyyah Expounds on Islam, trans. and ed. Muhammad 'Abdul-Haqq Ansari (Riyadh: Muhammad Ibn Sa'ud University, 2000), 30.

${ }^{12}$ See how al-Buti, who is a Sufi, approaches the question. Al-Buti, al-Salafiyya, 189.

${ }^{13}$ The word is also used in the plural. On the Internet, see the exhaustive compilation by the Saudi-based Salafi scholar Milfi al-Sa idi: http://fatwa1.com/anti-erhab/Salafiyah/tabseer.html (accessed 12 January 2010).

${ }^{14}$ In addition to the passages previously mentioned, see Ibn Taymiyya, Majmu ${ }^{c}, 4: 149,16: 471$; al-Dhahabi, Tadhkirat al-Huffaz, 4th ed. (Beirut: Dar Ihya' al-Turath, 1969), 4:1431. In another biographical dictionary, al-Dhahabi (d. 1374) writes that the famous hadith scholar al-Daraqutni (d. 995) was a Salafi who did not get involved in theological speculation and arguments. Idem, Siyar A 'lam al-Nubala', ed. Shu'ayb al-Arna'ut (Beirut: Mu'assasat al-Risala, 1985), 16:457.

${ }^{15}$ Ibn Kathir, al-Bidaya wa-l-Nihaya (Beirut: Maktabat al-Ma'arif, 1966), 13:333; Ibn 'Abd al-Hadi, al'Uqud al-Durriyya min Manaqib Shaykh al-Islam Ahmad ibn Taymiyya, ed. Muhammad Hamid al-Fiqi (Cairo: Matba 'at Hijazi, 1938), 87, 217; George Makdisi, Ibn Qudama's Censure of Speculative Theology (London: E. J. W. Gibb Memorial, 1962), 7.

${ }^{16}$ For more details on the methodological underpinnings of Salafi theology, see Haykel, "On the Nature of Salafi Thought," 38-42.

${ }^{17}$ Asma Asfaruddin cautions against falling into this pitfall when interpreting the word $\operatorname{shi}{ }^{{ }^{\top}} \bar{\imath}$. See Asma Asfaruddin, Excellence and Precedence: Medieval Islamic Discourse on Legitimate Leadership (Leiden: E. J. Brill, 2002), 284.

${ }^{18}$ See Basheer M. Nafi, "Abu al-Thana' al-Alusi: An Alim, Ottoman Mufti, and Exegete of the Qur'an," International Journal of Middle East Studies 34 (2002): 466. Nafi nonetheless acknowledges that the word salafi had a primarily theological connotation.

${ }^{19}$ Ibn Kathir, Tabaqat al-Fuqaha' al-Shafi 'iyyin, ed. Anwar al-Baz (al-Mansura, Egypt: Dar al-Wafa', 2004), 1:17, 185, 311. Many other jurists are listed as Ash'aris.

${ }^{20}$ Muhammad ibn Ahmad al-Saffarini, Kitab Lawa'ih al-Anwar al-Bahiyya wa-Sawati ${ }^{c}$ al-Asrar alAthariyya (Cairo: Matba' 'at Majallat al-Manar al-Islamiyya, 1905-1906), 1:18-19; Nu'man Khayr al-Din al-Alusi, Jala' al-'Aynayn fi Muhakamat al-Ahmadayn (n.p.: n.p., 1881), 25-26, 83; Abu al-Thana' al-Alusi, Ruh al-Ma'ani fi Tafsir al-Qur'an al- 'Azim wa-l-Sab` al-Mathani, 2nd ed. (Beirut: Dar Ihya' al-Turath alIslami, 1970), 1:60, 87; 'Abd al-Rahman al-Kawakibi, Umm al-Qura (Cairo: al-Sayyid al-Furati, 1899), 10, 70; Rashid Rida, Tafsir al-Qur'an al-Hakim al-Shahir bi-Tafsir al-Manar (Beirut: Dar al-Ma'rifa, 1970), $1: 251-55$.

${ }^{21}$ Quoted in Ibn 'Abd al-Hadi, al-'Uqud al-Durriyya, 117.

${ }^{22}$ Nafi, "Abu al-Thana' al-Alusi," 466, 488. In the endnotes, Nafi cites the statement twice from two different medieval authors (al-Karmi and Ibn 'Abd al-Hadi).

${ }^{23}$ Al-Dhahabi, Siyar A 'lam al-Nubala', 16:433; Ibn Rajab, al-Dhayl 'ala Tabaqat al-Hanabila, ed. 'Abd al-Rahman ibn Sulayman al- 'Uthaymin (Riyadh: Maktabat al- 'Abikan, 2005), 1:147. The first expression refers to the exegete Ibn Shahin (d. 995), who reportedly used it to describe his personal legal stance. The second expression was used by Ibn Taymiyya in his praise of the Hanbali Sufi scholar 'Abdallah al-Ansari (d. 1088). 


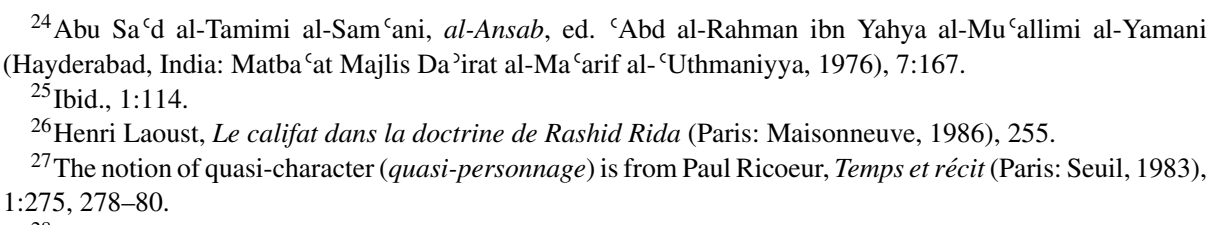

${ }^{28}$ Henri Laoust, "Le réformisme orthodoxe des 'Salafiya' et les caractères généraux de son orientation actuelle," Revue des études islamiques 2 (1932): 175.

${ }^{29}$ The Encyclopaedia of Islam arbitrarily connects the emergence of the salafiyya (Salafism) in various parts of the Muslim world with the influence of "Abduh and his ideas. See P. Shinar and W. Ende, "Salafiyya," $E I^{2}$. The ideas and principles of Salafism are further discussed in the article on reform (islā $h$ ), where the history of the salafiyya (the Salafis) is virtually interchangeable with that of Islamic reformism since 1884, the year in which al- 'Urwa al-Wuthqa was published. See A. Merad, "Islah," $E I^{2}$. For other examples, see Malcolm H. Kerr, Islamic Reform: The Political and Legal Theories of Muhammad 'Abduh and Rashid Rida (Berkeley, Calif.: University of California Press, 1966), 2-3; M. A. Zaki Badawi, The Reformers of Egypt (London: Croom Helm, 1978); and Daniel Brown, Rethinking Tradition in Modern Islamic Thought (Cambridge: Cambridge University Press, 1996), 30, 149.

${ }^{30}$ Reinhard Schulze, A Modern History of the Islamic World, trans. Azizeh Azodi (London: I. B. Tauris, 2000), 176.

${ }^{31}$ Revue du monde musulman, 36 (1918-19): 325; 59 (1925): 281, 312-13.

${ }^{32}$ This is particularly striking in the eighth volume of al-Manar dating from 1905. In one obituary, al-Afghani is merely presented as a philosopher. See al-Hilal 5 (1897): 562.

${ }^{33}$ Al-Manar 5 (1902): 405.

${ }^{34}$ Itzchak Weismann, "Between Sufi Reformism and Modernist Rationalism: A Reappraisal of the Origins of the Salafiyya From the Damascene Angle,” Die Welt des Islams 41 (2001): 231.

${ }^{35} \mathrm{~A}$ few relatively more ambiguous passages do exist, such as al-Kawakibi's lone statement that religious reform should derive from "the moderate Salafi wellspring" ('alä al-mashrab al-salafí al-mu'tadil). However, such statements are too rare and never sufficiently explicit to explain the entire conceptual edifice of Salafism qua Islamic modernism. See al-Kawakibi, Umm al-Qura, 140. Elsewhere in the book, Salafi epithets are clearly used as theological markers.

${ }^{36}$ Muhammad ibn Nasir al- 'Ajmi, al-Rasa'il al-Mutabadala bayna Jamal al-Din al-Qasimi wa-Mahmud Shukri al-Alusi (Beirut: Dar al-Basha'ir al-Islamiyya, 2001), 47, 60, 70-71, 163.

${ }^{37}$ Ibid., 115, 190.

${ }^{38}$ Rashid Rida, al-Wahda al-Islamiyya wa-l-Ukhuwwa al-Diniyya wa-Tawhid al-Madhahib (Cairo: alMaktab al-Islami, n.d.), 10.

${ }^{39}$ Rashid Rida, Yusr al-Islam wa-Usul al-Tashri ${ }^{\complement}$ al- ${ }^{\complement}$ Amm (Cairo: Matba 'at al-Manar, 1928), 77.

${ }^{40}$ Al-Manar 11 (1908): 95.

${ }^{41}$ Al-Manar 7 (1904): 51-52; 11 (1908): 205, 740-42; 29 (1928): 66-67.

${ }^{42}$ Al-Manar 8 (1905): 5.

${ }^{43}$ Al-Manar 16 (1913): 749

${ }^{44}$ Although his collaborators regarded him as a Salafi during his lifetime, the theological stance of Tahir al-Jaza'iri is open to question. His take on the Mu'tazilis is particularly intriguing. See Joseph H. Escovitz, “'He was the Muhammad 'Abduh of Syria:' A Study of Tahir al-Jaza'iri and His Influence," International Journal of Middle East Studies 18 (1986): 297-301. On the rationalist and modernist outlook of Jamal al-Din al-Qasimi, see David Commins, Islamic Reform: Politics and Social Change in Late Ottoman Syria (New York: Oxford University Press, 1990), 65-88.

${ }^{45}$ Muhibb al-Din al-Khatib, "Mudhakkirat Muhibb al-Din al-Khatib," in Min Siyar al-Khalidin biAqlamihim: Ahmad Shawqi, Muhammad al-Bashir al-Ibrahimi, Muhibb al-Din al-Khatib, ed. Hasan al-Samahi Suwaydan (Damascus: Dar al-Qadiri, 1998), 90-92.

${ }^{46}$ Ibid., 91.

${ }^{47}$ Ibid., 97-98.

${ }^{48}$ Ibid., 91-92.

${ }^{49}$ Ibid., 94; Filip di Tarazzi, Tarikh al-Sihafa al- 'Arabiyya (Beirut: al-Matba 'a al-Adabiyya, 1913), 2:52-56.

${ }^{50}$ Al-Khatib, "Mudhakkirat," 96, 126.

${ }^{51}$ Ibid., 119. 


\section{Henri Lauzière}

${ }^{52}$ Ibid., 141-42.

${ }^{53}$ See the advertisement at the end of Ibn Sina, Mantiq al-Mashriqiyyin wa-l-Qasida al-Muzdawija $f i$ al-Mantiq (Cairo: al-Maktaba al-Salafiyya, 1910), unpaginated.

${ }^{54}$ Muhibb al-Din al-Khatib and 'Abd al-Fattah Qatlan, Taqwim al-Majalla al-Salafiyya li-Sanat 1336/1918 (Cairo: Matba 'at al-Nahda, 1918), unpaginated.

${ }^{55}$ Al-Zahra' 2 (1926): 87; Sayyid Muhammad Rizvi, "Muhibb al-Din al-Khatib: A Portrait of a SalafistArabist (1886-1969)" (M.A. thesis, Simon Fraser University, 1991), 51.

${ }^{56} \mathrm{Al}$ - 'Ajmi, al-Rasa'il al-Mutabadala, 190. The actual terms that al-Alusi uses are salafi and khalafi. He links the latter to the Jahmis and Mu'tazilis.

${ }^{57}$ Abu Nasr al-Farabi, Mabadi' al-Falsafa al-Qadima (Cairo: al-Maktaba al-Salafiyya, 1910); Ibn Sina, Asbab Huduth al-Huruf (Cairo: al-Maktaba al-Salafiyya, 1913); idem, Mantiq.

${ }^{58}$ See the advertisement at the end of Ibn Sina, Mantiq, unpaginated.

${ }^{59}$ Al-Farabi, Mabadi', vi.

${ }^{60}$ See Richard Wood, al-Islam wa-l-Islah (Cairo: al-Maktaba al-Salafiyya, 1912), 6-11.

${ }^{61}$ Al-Manar 13 (1910): 470-72; al-Hilal 18 (1910): 607. Reviews from al-Muqtataf and al-Muqtabas are quoted at the end of Ibn Sina, Mantiq, unpaginated.

62 'Abd al-Fattah Qatlan, Fihris Maktabat al-Manar (Cairo: Matba'at al-Manar, 1914), 5; al-Fath 14 (1939): 6.

${ }^{63}$ Al-Khatib, "Mudhakkirat," 156-57.

${ }^{64}$ Al-Khatib and Qatlan, Taqwim al-Majalla al-Salafiyya, 2. Since 1910, al-Khatib and Qatlan had been in the habit of translating the back covers of their publications into English with the line "Published by the Salafyah [sic] Library." In January 1918, Qatlan slightly changed the English title of al-Majalla al-Salafiyya to "Salafiyah Review" (with an "i").

${ }^{65}$ Al-Majalla al-Salafiyya 1 (1917): 93.

${ }^{66}$ Al-Majalla al-Salafiyya 2 (1918): 63-64.

${ }^{67}$ Al-Khatib and Qatlan, Taqwim al-Majalla al-Salafiyya, 81-93.

${ }^{68}$ See his March 1909 letter to Anastase-Marie de Saint Élie reprinted in Daniel Massignon, ed., Autour d'une conversion: Lettres de Louis Massignon et de ses parents au père Anastase de Baghdad (Paris: Cerf, 2004), 57.

${ }^{69}$ Revue du monde musulman 34 (1916-18): 329-31.

${ }^{70}$ Revue du monde musulman 36 (1918-19): 325.

${ }^{71}$ Pierre Rocalve, Louis Massignon et l'islam (Damascus: Institut Français de Damas, 1993), 157; Revue du monde musulman 36 (1918-19): 272; 59 (1925): 312.

${ }^{72}$ For example, see Samuel G. Wilson, Modern Movements among Moslems (New York: Fleming H. Revell Company, 1916), 158, 160.

${ }^{73}$ Massignon cites the Salafiyya Bookstore in Revue du monde musulman 4 (1910): 295, 687.

${ }^{74}$ Daniel Massignon, Le voyage en Mésopotamie et la conversion de Louis Massignon en 1908 (Paris: Cerf, 2001), 17; al- 'Ajmi, al-Rasa'il al-Mutabadala, 169-70, 200; Revue du monde musulman 57 (1924): 245; Louis Massignon, "My Meetings with Maulana Azad," in Maulana Abul Kalam Azad: A Memorial Volume, ed. Humayun Kabir (New York: Asia Publishing House, 1959), 27-28.

${ }^{75}$ Lothrop Stoddard, The New World of Islam (New York: Charles Scribner's Sons, 1921), 86.

${ }^{76}$ The Moslem World 12 (1922): 21.

${ }^{77}$ Laoust, "Le réformisme orthodoxe," 175, 178, 222. On the first page, Laoust cites Massignon's 1919 remarks.

${ }^{78}$ Hamilton A. R. Gibb, Modern Trends in Islam (Chicago: Chicago University Press, 1947), 29, 35, 133.

${ }^{79}$ Contrary to common wisdom, neither Albert Hourani's Arabic Thought in the Liberal Age, 1798-1939, 3rd ed. (Cambridge: Cambridge University Press, 1983) nor Charles Adams' Islam and Modernism in Egypt (Oxford: Oxford University Press, 1933) mentions "Salafism" or salafiyya. These concepts are absent from the two books.

${ }^{80}$ One reformer who had access to Revue du monde musulman and encountered Massignon's use of Salafi labels is Muhammad Bahjat al-Athari, A $^{`}$ lam al- ' $I r a q$ (Cairo: al-Matba' 'a al-Salafiyya, 1926), 199.

${ }^{81}$ Lothrop Stoddard, Hadir al- ' Alam al-Islami, ed. Shakib Arslan, trans. 'Ajjaj Nuwayhid (Cairo: al-Matba'a al-Salafiyya, 1925), 1:173-74.

${ }^{82}$ Yusuf al-Dijwi, Kalima fi al-Salafiyya al-Hadira (Damascus: Maktabat al-Qudsi wa-1-Budayr, 1930), $2-7$. 
${ }^{83}$ Al-Khatib, "Mudhakkirat," 170.

84 'Ajjaj Nuwayhid, Sittun 'Aman ma'a al-Qafila al-'Arabiyya, ed. Bayan Nuwayhid al-Hut (Beirut: Dar al-Istiqlal, 1993), 41.

${ }^{85}$ Hammadi ibn 'Ali Muhammad, Awa'il al-Matbu'at al-Sa'udiyya: Qa'ima Mukhtara (Riyadh: Maktabat al-Malik Fahd al-Wataniyya, 1999), 41, 46, 48, 53, 58.

${ }^{86} \mathrm{He}$ must not be confused with his famous relative, Muhammad Husayn Nasif, who died the same year in Ta'if. See Muhammad 'Ali Maghribi, A'lam al-Hijaz fi al-Qarn al-Rabi' 'Ashr li-l-Hijra (Jeddah, Saudi Arabia: Tihama, 1981), 1:215, 268.

87 'Abbas ibn Salih Tashkandi, al-Tiba' a fi al-Mamlaka al-'Arabiyya al-Sa'udiyya, 1300h-1419h (Riyadh: Maktabat al-Malik Fahd al-Wataniyya, 1999), 182-91.

${ }^{88}$ Muhammad, Awa'il al-Matbu' at al-Sa' $u d i y y a, 59,64$.

${ }^{89}$ René Descartes, Maqal ' an al-Manhaj li-Ahkam Qiyadat al-'Aql wa-li-l-Bahth 'an al-Haqiqa fi al-'Ulum, trans. and ed. Mahmud Muhammad al-Khudayri (Cairo: al-Matba'a al-Salafiyya, 1929).

${ }^{90}$ See the book reviews in al-Zahra' 3 (1926): 77, 536, 602.

${ }^{91}$ Al-Fath 3 (1929): 664, 775.

${ }^{92}$ Laoust, "Le réformisme orthodoxe," 182, 190.

${ }^{93}$ Ibid., 176, 178.

94 'Umar ibn 'Abd al- 'Aziz, Musnad (Multan, Pakistan: Matba 'at al-Dukhaniyya, 1921), 1.

${ }^{95}$ Muhammad, Awa'il al-Matbu'at al-Sa'udiyya, 39; Adham Al Jundi, A'lam al-Adab wa-l-Fann (Damascus: Al Jundi, 1954), 1:225; Muhammad ibn Nasir al- 'Ajmi, 'Allamat al-Sham 'Abd al-Qadir ibn Badran al-Dimashqi: Hayatuhu wa-Atharuhu (Beirut: Dar al-Basha`ir al-Islamiyya, 1996), 49.

${ }^{96}$ Al-Fath 12 (1937): 566.

${ }^{97}$ Schulze, A Modern History, 95-96. 